\title{
PERTANGGUNGJAWABAN PIDANA MEDIA OT ATAS PEMBERITAAN TIDAK BENAR BERDASARKAN UNDANG-UNDANG NOMOR 40 TAHUN 1999 TENTANG PERS
}

\author{
Katon Fajar Maulana, Ami Setyaningrum \\ Fakultas Hukum Universitas Hang Tuah Surabaya \\ Jl. Arief Rachman Hakim Nomor 150, Keputih, Sukolilo, Surabaya \\ E-mail : katonfajar.m@outlook.com
}

\begin{abstract}
The purpose of this paper is to deeply understand criminal offense committed by the press for having announces that chief editor of the private television has caught by KPK hand fishing operation with the aim of making bombastic news, of course, the mass media in this case OT media will have a huge advantage over the news. The results showed that OT media in informing the US was caught in the KPK hand fishing Operation (KPK HFO) be accountable for their crime by the Press Law because; Based on the news that is not true, which stating that the US was caught KPK, the online media has violated Article 5 (1) of the Press Law, which determines that the national press is obliged to proclaim the events and opinions with respect religious norms and a sense of decency community as well as the presumption of innocence. In this case the media OT violates the presumption of innocence; Media OT does not carry out the role of the press as set forth in the provisions of Press law Article 6 letter $C$, which develop public opinion based on information that is precise, accurate, and true. Coverage improper done by media OT impressed incite people to cause controversy among the public; to determine Corporate criminal liability of the OT media is by using the theory of criminal liability Vicarious Liability, because the subject is corporate crime after the devolution of criminal liability of its officers, in this case the editor in chief in accordance with the explanation of Article 12 in conjunction with Article 18 of the Press Law. Based on the Fault made by the OT media, the online media can be penalized as provided for in Article 18 of the Press Law, which is subject to a maximum fine of Rp. 500,000,000.00.
\end{abstract}

Keywords: Corporate Criminal Liability, Online Media, Press Criminal Act

\begin{abstract}
Abstrak
Dalam penulisan ini ingin memahami secara mendalam tindak pidana yang dilakukan oleh pers karena telah memberitakan bahwa Pemimpin Redaksi televisi swasta telah tertangkap KPK saat operasi tangkap tangan yang dengan tujuan membuat berita yang bombastis,tentunya media massa dalam hal ini media OT akan mendapat keuntungan yang besar atas pemberitaan tersebut.Hasil penelitian menunjukan bahwa media OT dalam memberitakan AS telah tertangkap tangan KPK saat operasi tangkap tangan (OTT KPK) dapat dimintakan pertanggungjawaban pidana berdasarkan Undang-Undang Pers karena; Berdasarkan pemberitaan yang tidak benar, yang menyatakan bahwa AS tertangkap tangan KPK, maka media OT telah melanggar Pasal 5 ayat (1) Undang-Undang Pers, yang
\end{abstract}


menentukan bahwa Pers nasional berkewajiban memberitakan peristiwa dan opini dengan menghormati norma-norma agama dan rasa kesusilaan masyarakat serta asas praduga tidak bersalah. Dalam hal ini media OT melanggar asas praduga tidak bersalah; Media OT tidak melaksanakan peranan pers seperti yang tercantum dalam ketentuan Pasal 6 huruf C UndangUndang Pers, yaitu mengembangkan pendapat umum berdasarkan informasi yang tepat, akurat, dan benar. Pemberitaan yang tidak benar yang dilakukan oleh media OT terkesan menghasut masyarakat yang dapat menimbulkan kontroversi di kalangan masyarakat; Pertanggungjawaban pidana korporasi media OT ini menggunakan teori pertanggungjawaban pidana Vicarious Liability, karena yang dikenai pidana adalah korporasinya setelah ada pelimpahan pertanggungjawaban pidana dari pengurusnya, dalam hal ini pemimpin redaksi sesuai dengan penjelasan Pasal 12 juncto Pasal 18 Undang-Undang Pers. Berdasarkan kesalahan yang dilakukan oleh media OT, maka media OT dapat dikenakan sanksi sebagaimana yang diatur dalam Pasal 18 Undang-Undang Pers, yaitu dikenai pidana denda paling banyak Rp. 500.000.000,00.

\section{Kata Kunci: Pertanggungjawaban Korporasi, Media Online, Delik Pers.}

\section{A. PENDAHULUAN}

Media OT pada hari kamis tanggal 17 Juli 2014 memberitakan terkait operasi tangkap tangan (OTT) yang dilakukan oleh penyidik Komisi Pemberantasan Korupsi (KPK) terhadap Bupati Karawang Ade Swara dan beberapa pihak lainnya. Dalam kasus ini, media OT memberitakan penangkapan itu terkait suap Pilpres 2014. Dalam konteks itulah media OT menyebut AS yang merupakan pemimpin redaksi televisi nasional dan juga merupakan anggota tim pemenangan salah satu calon presiden termasuk salah satu pihak yang ditangkap KPK.

Pemberitaan inilah yang membuat AS merasa difitnah karena faktanya memang dia tidak berada pada saat adanya OTT KPK tersebut. Bahkan dikuatkan dengan pernyataan juru bicara KPK Johan Budi bahwa Operasi Tangkap Tangan di Karawang tidak terkait dengan penyelenggaraan Pilpres. Oleh karena pemberitaan tersebut, AS melaporkan media OT ke Badan Reserse dan Kriminal (Bareskrim) Mabes Polri pada hari jumat tanggal 18 Juli 2014 dengan pengaduan pencemaran nama baik sesuai ketentuan Pasal 310 KUHP.

Menurut berita yang dikutip dari Tribunnews.com pada tanggal 18 Juli 2014 pukul 11:27 yang berjudul "Diberitakan Tertangkap KPK, Arya Sinulingga Polisikan Tempo Online" mengatakan bahwa:

Arya Sinulingga melaporkan media "Tempo" ke Bareskrim Mabes Polri, Jumat pagi tanggal 18 Juli 2014. Saat membuat laporan ke Bareskrim, tampak Arya datang didampingi pula oleh kuasa hukumnya, Habiburahman. "Saya mau melaporkan Tempo sebagai media, ya penanggung jawabnya. Kami mau laporkan, hubungan dengan informasi yang kami lihat broadcast massage di tempat yang diubah beritanya, 
mengenai kabar tertangkapnya saya di KPK, tangkap tangan," tutur Arya di Bareskrim Mabes Polri. ${ }^{1}$

Sedangkan menurut berita yang dikutip dari rakyatsulsel.com pada tanggal 18 Juli 2014 pukul 14:10 yang berjudul "Arya Sinulingga Laporkan Tempo ke Mabes Polri” mengatakan bahwa:

Buntut pemberitaan operasi tangkap tangan Komisi Pemberantasan Korupsi, media online Tempo resmi dilaporkan ke Bareskrim Mabes Polri. Pelapornya adalah Arya Sinulingga. Arya yang datang didampingi kuasa hukumnya, Habiburahman, menilai Tempo telah melakukan pencemaran nama baik dengan mengabarkan bahwa dirinya telah ditangkap KPK. Yang juga dikeluhkannya, berita Tempo tersebut telah tersebar kemana-mana, termasuk di jejaring sosial twitter. Di situ tertulis bahwa salah satu tim sukses calon presiden Prabowo Subianto-Hatta Rajasa ditangkap karena kasus suap. "Saya melaporkan Tempo sebagai media, ya penanggung jawabnya. Kami mau laporkan, hubungan dengan informasi yang kami lihat broadcast massage di tempat yang diubah beritanya, mengenai kabar tertangkapnya saya di KPK, tangkap tangan," tutur Arya di Bareskrim Mabes Polri. "Ini fitnah dan pencemaran nama baik. Tempo sudah menghubungi saya, tapi tidak saya respon" imbuh arya. ${ }^{2}$

\section{B. PERUMUSAN MASALAH}

Berdasarkan uraian latar belakang diatas, dapat ditarik sebuah rumusan permasalahan terkait bagaimanakah bentuk tanggung jawab pidana yang dilakukan oleh Media OT atas pemberitaan tidak benar yang telah mereka lakukan

\section{METODE PENELITIAN}

Untuk menjawab permasalahan yang telah dirumuskan dalam penulisan ini,maka metode penelitian yang digunakan berupa penelitian hukum yuridis normatif,yaitu merupakan penelitian yang didasarkan pada peraturan perundang-undangan yang berlaku sebagai acuan utamanya, dalam hal ini Adalah bahan hukum yang mempunyai kekuatan hukum yang mengikat dengan menggunakan Kitab Undang-Undang Hukum Pidana, sertaperaturan perundang-undangan lainya yang berkaitan dengan bahan hukum primer sebelumnya.Pendekatan yang dipergunakan dalam penulisan skripsi ini adalah "Statute Approach" dan "Conceptual Approach". Statute Approach adalah pendekatan yang dilakukan dengan menggunakan pendekatan perundang-undangan yang berlaku terkait dengan permasalahan yang akan dibahas.Conceptual Approach adalah pendekatan yang dilakukan oleh peneliti dengan cara membahas pendapat para sarjana sebagai landasan pendukung.Penulisan skripsi ini menggunakan bahan hukum primer dan sekunder yang diperoleh dari inventarisasi, dan selanjutnya bahan hukum tersebut akan diklasifikasikan menurut obyek penelitian yang dalam hal ini berkaitan dengan materi yang dibahas, serta pada akhirnya bahan-bahan hukum tersebut disistematisasikan. Pada langkah analisis, guna

\footnotetext{
${ }^{1}$ http://m.tribunnews.com/nasional/2014/07/18/diberitakan-tertangkap-kpk-arya-sinu-lingga-polisikan-tempoonline. (Diakses pada 5/12/2018).

${ }^{2}$ http://rakyatsulsel.com/arya-sinulingga-laporkan-tempo-ke-mabes-polri-html. (Diakses pada 5/12/2018).
} 
memperoleh suatu jawaban maka akan digunakan penalaran deduktif, serta dalam menjawab permasalahan tersebut digunakan penafsiran sistematis.

\section{HASIL DAN PEMBAHASAN}

Hukum pidana yang berlaku di Negara Indonesia menggunakan hukum yang tertulis, di mana tindak pidana harus memenuhi aturan hukum yang telah ada yaitu peraturan perundangundangan. Seperti yang dituangkan dalam asas dasar hukum pidana yaitu asas legalitas yang tercantum dalam Pasal 1 ayat (1) KUHP, yang dikenal dalam bahasa latin sebagai "Nullum Delictum, Nulla Poena Sine Praevia Lege.” Yang artinya: “Tidak ada suatu perbuatan yang dapat dihukum, kecuali berdasarkan ketentuan pidana menurut Undang-Undang yang telah ada terlebih dahulu daripada perbuatannya itu sendiri".Delik Pers diatur dalam UndangUndang Republik Indonesia Nomor 40 Tahun 1999 tentang PERS. Dikaitkan dengan kasus media OT yang melakukan pemberitaan tidak benar atas AS telah memenuhi asas legalitas dalam hukum pidana karena perbuatan yang dilakukan oleh media OT telah diatur secara khusus dalam Undang-Undang Pers.

Pasal 3 Undang-undang Pers mengatur mengenai fungsi pers, yaitu:

1. Pers Nasional mempunyai fungsi sebagai media informasi, pendidikan, hiburan, dan kontrol sosial.

2. Di samping fungsi-fungsi tersebut ayat (1), Pers Nasional dapat berfungsi sebagai lembaga ekonomi

Dengan menyebut bahwa AS telah tertangkap tangan KPK, maka media OT yang mempunyai fungsi sebagai media informasi, pendidikan dan kontrol sosial telah melakukan kesalahan. Hal ini berarti media OT tidak melaksanakan fungsinya sebagaimana yang diatur pada Pasal 3 ayat (1) Undang-Undang Pers yang menentukan bahwa, "Pers Nasional mempunyai fungsi sebagai media informasi, pendidikan, hiburan, dan kontrol sosial." Dengan adanya pemberitaan yang tidak benar maka media OT akan memberikan informasi yang menyesatkan dan menggiring opini masyarakat untuk berasumsi bahwa AS memang benar telah tertangkap tangan KPK.

Selain itu hal ini juga membuktikan bahwa media OT tidak melaksanakan peranan pers seperti yang tercantum dalam ketentuan Pasal 6 Undang-Undang Pers yang menentukan bahwa: Pers nasional melaksanakan peranannya sebagai berikut:

1. memenuhi hak masyarakat untuk mengetahui;

2. menegakkan nilai-nilai dasar demokrasi, mendorong terwujudnya supremasi hukum, serta menghormati kebhinekaan;

3. mengembangkan pendapat umum berdasarkan informasi yang tepat, akurat dan benar;

4. melakukan pengawasan, kritik, koreksi, dan saran terhadap hal-hal yang berkaitan dengan kepentingan umum; dan

5. memperjuangkan keadilan dan kebenaran. 
Dalam hal ini media OT telah melanggar peranan pers huruf c yaitu mengembangkan pendapat umum berdasarkan informasi yang tepat, akurat dan benar. Adapun pengertian informasi yang tepat adalah berita yang dimuat harus berdasarkan fakta yang benar-benar terjadi. Informasi yang akurat adalah berita yang ditulis oleh wartawan harus berdasarkan sumber yang terpercaya serta memeriksa ulang keterangan dan fakta yang ditemuinya. Informasi yang benar adalah seorang wartawan dalam membuat suatu berita haruslah berdasarkan apa yang dilihat dan didengarnya sendiri bukan berasal dari orang lain. Media OT yang memberitakan AS dengan mengatakan bahwa salah satu tim sukses calon presiden Prabowo Subianto-Hatta Rajasa yang juga merupakan pemimpin redaksi televisi swasta nasional ditangkap karena kasus suap pada saat operasi tangkap tangan (OTT) oleh KPK pada hari kamis tanggal 17 Juli 2014. Berita tersebut tidak berdasarkan informasi yang tepat lantaran pada saat terjadi OTT KPK AS tidak berada ditempat dan tidak berdasarkan informasi yang akurat. Pada faktanya, pemberitaan yang dilakukan oleh media OT telah dibantah oleh juru bicara KPK Johan Budi serta pemberitaan tidak benar yang dilakukan oleh media OT terkesan menghasut masyarakat yang dapat menimbulkan kontroversi di kalangan masyarakat.

Pasal 5 Undang-Undang Pers menentukan kewajiban pers ialah:

1. Pers nasional berkewajiban memberitakan peristiwa dan opini dengan menghormati norma-norma agama dan rasa kesusilaan masyarakat serta asas praduga tak bersalah.

2. Pers wajib melayani Hak Jawab.

3. Pers wajib melayani Hak Koreksi.

Adapun pengertian asas praduga tak bersalah adalah dimana seseorang belum dinyatakan bersalah sebelum diputus dengan kekuatan hukum yang tetap (inkracht) oleh pengadilan.

Menurut Wina Armada Sukardi menyatakan sebagai berikut ${ }^{3}$ :

Asas praduga tidak bersalah dalam bidang pers, penerapannya memiliki sedikit perbedaan dengan bidang hukum. Pada intinya, penerapan asas praduga tidak bersalah dalam pers bermakna pers dalam pemberitaannya tidak boleh menghakimi. Larangan untuk membuat pemberitaan yang menghakimi dalam pers tidak hanya terbatas pada pemberitaan yang sudah menyangkut proses pelaksanaan atau penegakan hukum belaka, tetapi mencakup pada semua pemberitaan. Pada berita apapun, pers harus tetap menghormati asas praduga tidak bersalah.

Kasus pemuatan berita AS ini bertentangan dengan Pasal 5 ayat (1) Undang-Undang Pers yakni asas praduga tidak bersalah. Media OT yang menuduh AS tertangkap tangan KPK tanpa ada bukti yang pasti dan tanpa ada konfirmasi dari yang bersangkutan serta telah dibantah berita tersebut oleh Juru bicara KPK Johan Budi. Media OT telah melanggar hak-

\footnotetext{
${ }^{3}$ Sukardi, Wina Armada, Asas Praduga Tidak Bersalah Dalam Praktek Pers, Dewan Pers, Jakarta: 2010, hlm. 55
} 
hak sipil individu, membuat berita yang menghakimi serta mencederai nama baik orang lain. Seseorang tidak boleh langsung menuduh orang lain sebelum yang dituduhnya ini telah nyata terbukti melakukan apa yang disangkanya dalam hal ini dibuktikan dengan adanya putusan pengadilan yang telah mempunyai kekuatan hukum yang tetap bahwa ia telah nyata bersalah. Pada berita ini, media OT tidak menghormati asas praduga tidak bersalah.

Menurut Oemar Seno Adji ada tiga kriteria untuk merumuskan suatu delik yang dikualifikasikan sebagai delik pers, yaitu ${ }^{4}$ :

1. harus dilakukan dengan barang cetakan;

2. perbuatan yang dipidana harus terdiri atas pernyataan, pikiran atau perasaan; dan

3. dari perumusan delik harus ternyata bahwa publikasi merupakan suatu syarat untuk menumbuhkan suatu kejahatan, apabila kejahatan tersebut dilakukan dengan suatu tulisan.

Adapun pengertian barang cetakan yang dimaksud merupakan barang cetakan sebagai sarana pers dalam arti sempit berupa buku, majalah, tabloid atau dalam arti luas berupa mass communication dimana didalamnya terdapat sandiwara, radio, orasi-orasi, film maupun video $^{5}$. Sedangkan untuk perbuatan yang dipidanakan harus terdiri atas pernyataan pikiran atau perasaan pers dalam bentuk tulisan yang berkaitan dengan barang cetakan tersebut. Publikasi dalam hal ini merupakan syarat untuk dapat menumbuhkan suatu kejahatan, akan tetapi publikasi dapat menumbuhkan suatu kejahatan apabila suatu fikiran atau perasaan telah diumumkan atau disebarluaskan kepada khalayak umum dan isi buah fikiran atau perasaan yang diumumkan mengandung suatu kejahatan atau yang dapat dihukum dan cara pengumumannya dilakukan dengan percetakan. Media OT yang memberitakan AS tertangkap tangan KPK pada hari kamis tanggal 17 Juli 2014. Berita tersebut menjadi Headline pemberitaan media OT. Maka berita yang ditulis oleh media OT dikualifiksikan sebagai barang cetakan karena berita tersebut merupakan karya wartawan media elektronik. Berita yang telah dibuat oleh media OT merupakan suatu pernyataan atau opini. Media OT yang memberitakan AS tertangkap tangan KPK, namun berita tersebut telah dibantah langsung oleh Juru Bicara KPK Johan Budi. Ini menandakan bahwa berita yang ditulis oleh media OT tidak berdasarkan fakta melainkan hanya gagasan atau opini dari wartawan media OT. Media OT telah memenuhi syarat yang ketiga yakni publikasi, berita yang ditulis oleh media OT terkait kabar tertangkapnya AS saat OTT KPK pada hari kamis tanggal 17 Juli 2014 dipublikasikan melalui website media OT yakni www.tempo.co. Dengan demikian, media OT telah memenuhi tiga kriteria ditas dan dikualifikasikan sebagai delik pers.

Ketentuan tentang fitnah terdapat dalam ketentuan Pasal 310 KUHP yang menentukan:

Kejahatan penghinaan atau menista, yang menetapkan:

1. Barangsiapa sengaja menyerang kehormatan atau nama baik seseorang dengan menuduhkan sesuatu hal, yang maksudnya terang supaya hal itu diketahui umum,

\footnotetext{
${ }^{4}$ Oemar Seno Adji, Perkembangan Delik Pers di Indonesia, Erlangga, Jakarta: 1990, hlm. 21

${ }^{5}$ Pusat Bahasa Departemen Pendidikan Nasional, Kamus Besar Bahasa Indonesia, Balai Pustaka, Jakarta: 2002.
} 
diancam karena pencemaran dengan pidana penjara paling lama sembilan bulan atau pidana denda paling banyak empat ribu lima ratus rupiah.

2. Jika hal itu dilakukan dengan tulisan atau gambaran yang disiarkan, dipertunjukkan atau ditempelkan di muka umum, maka diancam karena pencemaran tertulis dengan pidana penjara paling lama satu tahun empat bulan atau pidana denda paling banyak empat ribu lima ratus rupiah.

3. Tidak merupakan pencemaran atau pencemaran tertulis, jika perbuatan jelas dilakukan demi kepentingan umum atau karena terpaksa untuk membela diri.

Menurut Soesilo", yang dimaksud penghinaan adalah "menyerang kehormatan dan nama baik seseorang". Yang diserang ini biasanya merasa "malu" "Kehormatan" yang diserang di sini hanya mengenai kehormatan tentang "nama baik", bukan "kehormatan" dalam lapangan seksuil, kehormatan yang dapat dicemarkan karena tersinggung anggota kemaluannya dalam lingkungan nafsu birahi kelamin. Perbuatan yang menyinggung kehormatan dalam lapangan seksuil ini tidak termasuk dalam kejahatan penghinaan, akan tetapi masuk kejahatan kesopanan atau kejahatan kesusilaan. Dalam hal tindak pencemaran nama baik, maka perbuatan tersebut harus dilakukan dengan unsur kesengajaan. Unsur yang harus ada dalam tindak pidana pencemaran nama baik adalah kesengajaan sebagai maksud, yaitu agar diketahui oleh masyarakat umum dan membuat nama orang lain tercemar.

Berdasarkan ketentuan Pasal 310 ayat (1) KUHP menentukan bahwa "Barangsiapa sengaja menyerang kehormatan atau nama baik seseorang dengan menuduhkan sesuatu hal, yang maksudnya terang supaya hal itu diketahui umum, diancam karena pencemaran dengan pidana penjara paling lama sembilan bulan atau pidana denda paling banyak empat ribu lima ratus rupiah. Dari rumusan Pasal 310 ayat (1) KUHP, maka unsur-unsurnya adalah sebagai berikut:

1. Dengan sengaja

2. Menyerang kehormatan atau nama baik orang lain

3. Menuduh melakukan suatu perbuatan tertentu, dan

4. Dengan maksud yang nyata supaya diketahui oleh umum.

Adapun menurut Adami Chazawi, mengenai penjelasan unsur-unsur Pasal 310 KUHP adalah sebagai berikut ${ }^{7}$ :

1. Unsur Subjektif: Sengaja dan Maksud

Kejahatan pencemaran terdapat dua unsur kesalahan, yakni sengaja (opzettelijk) dan maksud atau tujuan. Walaupun dalam doktrin, maksud itu adalah juga kesengajaan (dalam arti sempit), yang disebut dengan kesengajaan sebagai maksud. Tetapi, fungsi unsur sengaja dan unsur maksud dalam pencemaran berbeda. Sikap

\footnotetext{
${ }^{6}$ R Soesilo., Kitab Undang-Undang Hukum Pidana (KUHP) Serta Komentar-Komentarnya Lengkap Pasal Demi Pasal, Politea Bogor, Bandung: 1998.

${ }^{7}$ Adami Chazawi, Pelajaran Hukum Pidana Bagian I, RajaGrafindo Perkasa, Jakarta: 2012, hlm. 28.
} 
batin "sengaja" ditujukan pada perbuatan menyerang kehormatan atau nama ba ik orang (perbuatan dan objek perbuatan). Sementara sikap batin "maksud" ditujukan pada unsur "diketahui oleh umum" mengenai perbuatan apa yang dituduhkan pada orang itu.

Maka unsur yang diliputi oleh sengaja adalah unsur-unsur berikut ini:

a. Perbuatan menyerang

b. Objek: kehormatan atau nama baik orang

c. Dengan menuduhkan suatu perbuatan tertentu.

Sementara unsur yang dituju oleh maksud adalah unsur terang supaya diketahui umum.

2. Perbuatan menyerang

Perbuatan menyerang (aanranden), tidaklah bersifat fisik, karena terhadap apa yang diserang (objeknya) memang bukan fisik tapi perasaan mengenai kehormatan dan perasaan mengenai nama baik orang.

3. Objek: Kehormatan dan nama baik orang

Objek yang diserang adalah rasa/perasaan harga diri mengenai kehormatan (eer), dan rasa/perasaan harga diri mengenai nama baik (goedennaam) orang. Rasa harga diri adalah intinya objek dari setiap penghinaan, yang menurut Wirjono Projodikoro adalah menjadikan ukuran dari penghinaan. Rasa harga diri dalam penghinaan adalah rasa harga diri dibidang kehormatan, dan rasa harga diri di bidang nama baik.

4. Caranya: dengan menuduhkan perbuatan tertentu.

Di atas telah diterangkan bahwa perbuatan menyerang ditujukan pada rasa harga diri atau martabat (mengenai kehormatan dan nama baik) orang, dengan menggunakan kata/kalimat melalui ucapan, caranya dengan menuduhkan suatu perbuatan tertentu. Jadi yang dituduhkan si pembuat haruslah merupakan perbuatan tertentu, dan bukan hal lain

Media OT yang memberitakan AS dengan mengatakan bahwa salah satu tim sukses calon presiden Prabowo Subianto-Hatta Rajasa yang juga merupakan pemimpin redaksi televisi swasta nasional ditangkap karena kasus suap pada saat operasi tangkap tangan (OTT) KPK pada hari kamis tanggal 17 Juli 2014 telah memenuhi unsur subyektif dari Pasal 310 ayat (1) KUHP yang mana media OT dengan sengaja memberitakan AS tertangkap tangan KPK. Unsur sengaja dalam hal ini ditujukan untuk diketahui umum. Unsur obyektif dari Pasal 310 ayat (1) KUHP juga telah terpenuhi yakni unsur menyerang pada kehormatan dan nama baik. Media OT yang melakukan pemberitaan tidak benar terhadap AS ini menyerang pada kehormatan dan nama baik AS. Menuduhkan perbuatan tertentu dalam hal ini melalui pemberitaan yang tidak benar. Media OT yang memberitakan bahwa AS tertangkap tangan 
KPK pada saat OTT KPK pada hari kamis tanggal 17 Juli 2014. Pada faktanya, pemberitaan yang dilakukan media OT telah dibantah oleh juru bicara KPK Johan Budi.

Sedangkan ketentuan Pasal 310 ayat (2) KUHP menentukan bahwa apabila dilakukan dengan tulisan atau gambaran yang disiarkan, dipertunjukkan atau ditempelkan dimuka umum, maka diancam karena pencemaran tertulis dengan pidana penjara paling lama satu tahun empat bulan atau pidana denda paling banyak empat ribu lima ratus rupiah. Rumusan Pasal 310 ayat (2) KUHP, jika dirinci terdapat unsur-unsur berikut:

1. Semua unsur (objektif dan subjektif) dalam ayat (1)

2. Menuduh melakukan perbuatan dengan cara/melalui tulisan atau gambar:

a. yang disiarkan;

b. yang dipertunjukkan; dan atau

c. yang ditempelkan.

Pencemaran dilakukan dengan menggunakan "tulisan dan gambar". Tulisan adalah hasil dari pekerjaan menulis baik dengan tangan maupun alat apapun yang wujudnya berupa rangkaian kata-kata/kalimat dalam bahasa apapun yang isinya mengandung arti tertentu (in casu menyerang kehormatan dan nama baik orang), diatas sebuah kertas atau benda lainnya yang sifatnya dapat ditulisi (misalnya: kertas, papan, kain). Sedangkan gambar atau gambaran atau lukisan adalah tiruan dari benda yang dibuat dengan coretan tangan melalui alat tulisan: pensil, kuas dan cat, dengan alat apapun di atas kertas atau benda lainnya yang sifatnya dapat digambari/ditulisi. Gambar ini harus mengandung suatu makna yang sifatnya mencemarkan nama baik atau kehormatan orang tertentu (yang dituju). Media OT yang menyebut AS termasuk salah satu pihak yang ditangkap oleh KPK dalam operasi tangkap tangan (OTT) pada hari kamis tanggal 17 Juli 2014 yang mana faktanya AS tidak berada ditempat pada saat adanya OTT KPK tersebut. Hal inilah yang membuat AS merasa difitnah. Media OT dengan sengaja memberitakan AS agar masyarakat umum mengetahui kabar tertangkapnya AS oleh KPK dan tentunya membuat nama AS tercemar akibat pemberitaan tersebut. Sehingga dapat dikatakan bahwa media OT telah memenuhi unsur Pasal 310 ayat (2) KUHP yang mana media OT melakukan pencemaran nama baik secara tertulis yang disiarkan melalui website media OT yakni www.tempo.co pada hari yang sama yakni hari Kamis tanggal 17 Juli 2014. Dalam cara menyebarkan sekian banyak tulisan atau gambar kepada khalayak ramai, telah nampak maksud media OT agar isi tulisan atau makna dalam gambar yang disiarkan, yang sifatnya penghinaan diketahui umum.

AS yang melaporkan media OT pada hari jumat tanggal 18 Juli 2014 dengan tuduhan pencemaran nama baik sesuai dengan ketentuan Pasal 310 ayat (2) KUHP tidaklah tepat karena KUHP masih menganut asas universitas delinquere non potest dimana KUHP tidak mengenal korporasi sebagai subyek hukum pidana. Tidak demikian halnya dengan berbagai undang-undang pidana di luar KUHP dalam hal ini Undang-Undang Pers. Menurut UndangUndang Pers, selain manusia, korporasi juga dapat menjadi subyek tindak pidana sehingga 
korporasi dapat dimintai pertanggungjawaban pidana. Selain itu terdapat suatu asas Lex Specialis derogat legi generali, yaitu asas yang memberlakukan ketentuan hukum yang bersifat khusus mengesampingkan ketentuan hukum yang bersifat umum karena itu ketentuan pidana tersebut dalam KUHP tidak dapat diterapkan terhadap perusahaan pers dalam hal ini media OT. Sebab Undang-Undang Nomor 40 Tahun 1999 tentang PERS jelas mengatur tindak pidana atau delik yang berlaku untuk perusahaan pers.

Pengertian Perusahaan Pers menurut Pasal 1 angka 2 Undang-Undang Pers menentukan: "Badan hukum Indonesia yang menyelenggarakan usaha pers meliputi perusahaan media cetak, media elektronik, dan kantor berita, serta perusahaan media lainnya yang secara khusus menyelenggarakan, menyiarkan atau menyalurkan informasi." Menurut Sutan Remy Sjahdeni ${ }^{8}$, membedakan arti korporasi dalam arti sempit dan arti luas dilihat dari bentuk hukumnya. Suatu korporasi dikatakan dalam arti sempit jika ia merupakan badan hukum. Dalam artinya yang luas korporasi dapat berbentuk badan hukum maupun bukan badan hukum. Media OT yang memberitakan AS ditangkap tangan KPK pada hari kamis malam tanggal 17 Juli 2014. Dalam kasus ini, media OT merupakan perusahaan pers yang tergabung dalam PT. Tempo Inti Media Tbk, sebuah kumpulan dari perusahaan-perusahaan media cetak dan elektronik seperti Tempo Tv, Tempo English Section, Koran Tempo, Majalah AHA!, Tempo.co dan beberapa media cetak lainnya. Perusahaan ini bisa disebut sebagai korporasi atau badan hukum yang menjalankan tugasnya di bidang jurnalistik yang merupakan subyek hukum berdasarkan Pasal 1 angka 2 Undang-Undang Pers. Korporasi atau badan hukum ini juga bisa dimintai pertanggung jawaban apabila ia melakukan kesalahan atau melanggar hukum.

Pengertian kejahatan korporasi menurut Clinard and Yeanger adalah "a corporate crime is any act comitted by corporations that is punished under administrative, civil or criminal law." Perilaku korporasi atau individual yang bertindak atas nama korporasi, yang dilarang oleh undang-undang dan yang bernilai ekonomis. Orientasi kejahatan korporasi tersebut adalah keuntungan atau profit. Dari pengertian kejahatan korporasi yang diberikan oleh Clinard and Yeanger dikaitkan dengan kasus media OT yang dengan sengaja melanggar peraturan pers agar berita yang dipublikasikan menarik banyak pembaca, yang pada akhirnya medianya akan semakin terkenal dan keuntungan yang diperolehnya bisa melonjak tajam sehingga dapat dikatakan perbuatan media OT termasuk kejahatan korporasi karena berorientasi pada keuntungan. Dengan kata lain media OT untuk mewujudkan tujuan utamanya sebagai korporasi melalui anomie of success yakni menghalalkan segala cara guna mendapatkan keuntungan.

Menurut Steven Box, sebagaimana dikutip oleh Arif Amrullah ada tiga bentuk kejahatan korporasi, yaitu? ${ }^{9}$ :

\section{Crime for corporation (corporate crime).}

\footnotetext{
${ }^{8}$ Sutan Remy Sjahdeni, Pertanggungjawaban Pidana Korporasi, Grafi Pers, Jakarta: 2007, hlm. 87.

${ }^{9}$ Amirullah, Arif, Kejahatan Korporasi, Bayumedia Publishing, Malang: 2006, hlm. 64.
} 


\section{Crime against corporation (employee crime).}

3. Criminal corporation.

Crime for corporation merupakan kejahatan yang dilakukan oleh korporasi untuk mencapai tujuan korporasi berupa perolehan keuntungan untuk kepentingan korporasi, atau dengan kata lain corporate crime is clearly committed for the corporate and not against it. Pelakunya bisa dilakukan oleh manager, employee yang memiliki syarat-syarat tertentu, yakni berfungsi dalam korporasi, mempunyai kewenangan memutus, putusannya dilaksanakan oleh korporasi.

Kasus media OT yang memberitakan AS tertangkap tangan KPK menjadi Headline pemberitaan website guna menarik banyak pembaca yang pada akhirnya medianya akan semakin terkenal dan banyak perusahaan iklan yang ingin memasukkan iklan di media OT tentu keuntungan yang diperolehnya bisa melonjak tajam. Ketika wartawan media OT menulis berita tentang tertangkap tangannya AS pada OTT KPK tentu telah melalui berbagai tahap mulai dari tahap pemeriksaan naskah berita dari kata per kata, penyempurnaan naskah dari bahasa Indonesia ke dalam bahasa jurnalistik. Hal itu semua dilakukan mulai dari wartawan, redaktur, redaktur pelaksana sampai kepada pemimpin redaksi. Mereka semua mempunyai peranan dalam korporasi dalam hal ini media OT. Sehingga dapat dikatakan pemberitaan yang dilakukan oleh media OT termasuk bentuk kejahatan korporasi yakni Crime for corporation (corporate crime).

Berkenaan dengan pembebanan pertanggungjawaban pidana kepada korporasi, menurut Sutan Remy Sjahdeini terdapat empat kemungkinan sistem pembebanan pertanggungjawaban pidana kepada korporasi. Keempat kemungkinan sistem yang dapat diberlakukan itu adalah ${ }^{10}$ :

1. Pengurus korporasi sebagai pelaku tindak pidana, sehingga oleh karenanya penguruslah yang harus memikul pertanggungjawaban pidana.

2. Korporasi sebagai pelaku tindak pidana, tetapi pengurus yang harus memikul pertanggungjawaban pidana.

3. Korporasi sebagai pelaku tindak pidana dan korporasi itu sendiri yang harus memikul pertanggungjawaban pidana.

4. Pengurus dan korporasi keduanya sebagai pelaku tindak pidana, dan keduanya pula yang harus memikul pertanggungjawaban pidana

Dari empat sistem pembebanan pertanggungjawaban pidana korporasi yang paling tepat diterapkan dalam kasus media OT yang telah melakukan pemberitaan tidak benar terhadap AS adalah sistem pembebanan pertanggungjawaban yang keempat. Karena apabila yang dibebani pertanggungjawaban pidana hanya korporasi sedangkan pengurus tidak harus memikul tanggung jawab maka pengurus akan selalu berlindung di balik punggung korporasi untuk melepaskan dirinya dari tanggung jawab dengan alasan bahwa perbuatannya itu bukan merupakan perbuatan pribadi dan bukan untuk kepentingan pribadi, tetapi merupakan

\footnotetext{
${ }^{10}$ Sutan Remy, Op. Cit.
} 
perbuatan yang dilakukannya untuk dan atas nama korporasi dan untuk kepentingan korporasi.

Di dalam pertanggungjawaban hukum suatu korporasi, ada tiga teori yang digunakan, yaitu:

1. Vicarious Liability atau Respondeat Superior.

2. Teori Identifikasi (Identification Theory / The Alter Ego Theory).

3. Teori Delegasi (The Delegation Theory).

Menurut Sutan Remi Sjahdeini menyatakan bahwa ${ }^{11}$ :

Teori vicarious liability diterapkan dalam korporasi, berarti korporasi dimungkinkan harus bertanggung jawab atas perbuatan-perbuatan yang dilakukan oleh para pegawainya, kuasanya, atau mandatarisnya, atau siapa pun yang bertanggung jawab kepada korporasi tersebut. Penerapan teori ini hanya dapat dilakukan setelah dapat dibuktikan bahwa memang terdapat hubungan subordinasi antara pemberi kerja dan orang yang melakukan tindak pidana tersebut.

Dari tiga teori yang melandasi pertanggungjawaban pidana dalam korporasi jika dikaitkan dengan kasus media OT maka teori pertanggungjawaban pidana dalam korporasi yang paling tepat adalah teori Vicarious Liability. Pembebanan pertanggungjawaban pidana korporasi hanya mungkin dilakukan secara Vicarious Liability. Segala perbuatan hukum yang benar atau salah, baik dalam lapangan keperdataan maupun yang diatur oleh ketentuan pidana, dilakukan oleh manusia yang menjalankan kepengurusan korporasi. Korporasi dimungkinkan harus bertanggungjawab atas perbuatan yang dilakukan oleh para pegawainya, kuasanya, atau mandatarisnya, atau siapa pun yang bertanggung jawab kepada korporasi tersebut. Dalam hal ini memang nyata terdapat hubungan subordinasi antara pemberi kerja dalam hal ini adalah media OT dan orang yang melakukan tindak pidana dalam hal ini berprofesi sebagai wartawan dari media OT.

Berbicara tentang pertanggungjawaban pidana, subyek hukumnya adalah badan hukum yang dalam hal ini adalah perusahaan pers sebagaimana tertuang dalam ketentuan Pasal 9 Undang-Undang Pers. Perusahaan pers sebagai subyek hukum pidana dalam hal pertanggungjawabannya diserahkan pada pimpinan bidang redaksi sesuai dengan penjelasan Pasal 12 juncto Pasal 18 Undang-Undang Pers.

Pasal 18 Undang-Undang Pers mengatur mengenai ketentuan pidana,yaitu:

1. Setiap orang yang secara melawan hukum dengan sengaja melakukan tindakan yang berakibat menghambat atau menghalangi pelaksanaan ketentuan Pasal 4 ayat (2) dan ayat (3) dipidana dengan pidana penjara paling lama 2 (dua) tahun atau denda paling banyak Rp. 500.000.000,00 (lima ratus juta rupiah).

2. Perusahaan pers yang melanggar ketentuan Pasal 5 ayat (1) dan ayat (2), serta Pasal 13 dipidana dengan pidana denda paling banyak Rp. 500.000.000,00 (lima ratus juta rupiah).

\footnotetext{
${ }^{11}$ Ibid.
} 
3. Perusahaan pers yang melanggar ketentuan Pasal 9 ayat (2) dan Pasal 12 dipidana dengan pidana denda paling banyak Rp. 100.000.000,00 (seratus juta rupiah).

Berdasarkan penjelasan diatas dapat disimpulkan bahwa pemberitaan yang dilakukan oleh media OT kepada AS dapat dimintai pertanggungjawaban pidana dengan mendasar pada Pasal 18 ayat (2) Undang-Undang Pers karena didalamnya tersirat atau terkandung Trial by the press yang dipidana dengan pidana denda paling banyak Rp. 500.000.000,00 (Lima ratus juta rupiah). Hal ini disebabkan karena dalam menulis berita media OT tidak berdasarkan fakta dimana wartawan media OT melihat, mendengar dan tidak mengada serta disaksikan orang lain. Jadi judul dan pemberitaan tersebut yang telah disebarluaskan untuk umum dimana AS diberitakan tertangkap tangan oleh KPK telah melanggar asas praduga tidak bersalah sebagaimana yang telah dijabarkan pada ketentuan Pasal 5 Undang-Undang Pers.

Pasal 1 Kode Etik Jurnalistik mengatur mengenai kepribadian dan intregitas wartawan, yaitu wartawan Indonesia bersikap independen, menghasilkan berita yang akurat, berimbang dan tidak beriktikad buruk.

Dalam hal ini Wartawan media OT telah melanggar ketentuan Pasal 1 Kote Etik Jurnalistik dengan menghasilkan berita yang tidak akurat. Adapun pengertian akurat adalah berita yang ditulis oleh wartawan harus berdasarkan sumber yang terpercaya serta memeriksa ulang keterangan dan fakta yang ditemuinya. Berdasarkan ketentuan Kode Etik Jurnalistik, penilaian akhir atas pelanggaran kode etik jurnalistik dilakukan oleh Dewan Pers. Sedangkan sanksi atas pelanggaran kode etik jurnalistik dilakukan oleh organisasi wartawan dan atau perusahaan pers.

Pasal 4 Peraturan Rumah Tangga PWI mengatur mengenai sanksi, yaitu:

1. Organisasi dapat menjatuhkan tindakan organisatoris terhadap anggota karena satu di antara hal-hal berikut:

a. oleh Dewan Kehormatan dinyatakan telah melanggar Kode Etik Jurnalistik dan dijatuhi tindakan pemberhentian sementara atau pemberhentian penuh dari keanggotaan;

b. melakukan perbuatan yang merendahkan martabat, kredibilitas dan integritas profesi serta organisasi;

c. melakukan pelanggaran terhadap Peraturan Dasar dan Peraturan Rumah Tangga PWI;

d. menyalahgunakan nama organisasi untuk kepentingan diri sendiri atau orang lain;

e. Terbukti tidak lagi melaksanakan profesi pekerjaan kewartawanan; dan

f. Dijatuhi hukuman oleh pengadilan karena melakukan tindak pidana.

2. Tindakan organisasi dapat berupa:

a. peringatan keras;

b. pemberhentian sementara; dan

c. pemberhentian penuh. 
Dari uraian diatas, wartawan media OT yang telah melanggar Kode Etik Jurnalistik yakni menghasilkan berita yang tidak akurat, maka wartawan media OT dapat dikenakan sanksi sebagaimana yang diatur dalam ketentuan Pasal 4 Peraturan Rumah Tangga PWI, yaitu dikenai sanksi berupa peringatan keras, pemberhentian sementara serta pemberhentian penuh. Pada dasarnya Undang-Undang Pers hanya mengatur pers secara umum saja, akan tetapi hal-hal yang menyangkut sikap tindak pers diatur lebih lanjut dalam Kode Etik Jurnalistik.

\section{E. PENUTUP}

\section{Kesimpulan}

Berdasarkan uraian dan pembahasan pada bab sebelumnya, maka dapat disimpulkan bahwa media OT dalam memberitakan AS telah tertangkap tangan KPK saat operasi tangkap tangan (OTT KPK) dapat dimintakan pertanggungjawaban pidana berdasarkan Undang-Undang Pers karena:

a. Berdasarkan pemberitaan yang tidak benar, yang menyatakan bahwa AS tertangkap tangan KPK, maka media OT telah melanggar Pasal 5 ayat (1) Undang-Undang Pers, yang menentukan bahwa Pers nasional berkewajiban memberitakan peristiwa dan opini dengan menghormati norma-norma agama dan rasa kesusilaan masyarakat serta asas praduga tidak bersalah. Dalam hal ini media OT melanggar asas praduga tidak bersalah.

b. Media OT tidak melaksanakan peranan pers seperti yang tercantum dalam ketentuan Pasal 6 huruf C Undang-Undang Pers, yaitu mengembangkan pendapat umum berdasarkan informasi yang tepat, akurat, dan benar. Pemberitaan yang tidak benar yang dilakukan oleh media OT terkesan menghasut masyarakat yang dapat menimbulkan kontroversi di kalangan masyarakat.

c. Pertanggungjawaban pidana korporasi media OT ini menggunakan teori pertanggungjawaban pidana Vicarious Liability, karena yang dikenai pidana adalah korporasinya setelah ada pelimpahan pertanggungjawaban pidana dari pengurusnya, dalam hal ini pemimpin redaksi sesuai dengan penjelasan Pasal 12 juncto Pasal 18 Undang-Undang Pers.

d. Berdasarkan kesalahan yang dilakukan oleh media OT, maka media OT dapat dikenakan sanksi sebagaimana yang diatur dalam Pasal 18 Undang-Undang Pers, yaitu dikenai pidana denda paling banyak Rp. 500.000.000,00.

\section{Saran}

Hendaknya dalam Undang-Undang Nomor 40 Tahun 1999 tentang Pers khususnya asas praduga tak bersalah perlu diefektifkan agar tidak menimbulkan kontroversi di kalangan masyarakat serta tidak menimbulkan kerugian pada diri narasumber

\section{DAFTAR PUSTAKA}

\section{Buku}


Adji, Oemar Seno, Perkembangan Delik Pers di Indonesia, Erlangga, Jakarta: 1990,. , PERS Aspek-Aspek Hukum, Erlangga, Jakarta: 1977,.

Amirullah, Arief, Kejahatan Korporasi, Bayumedia Publishing, Malang: 2006.

Anwar, Moch., Hukum Pidana Bagian Khusus (KUHP buku II), Alumni Bandung: 1986.

Chazawi Adami, Pelajaran Hukum Pidana Bagian I, RajaGrafindo Perkasa, Jakarta: 2012.

Farid, Andi Zainal Abidin, Hukum Pidana I, Sinar Grafika, Jakarta: 2007.

Lamintang, P.A.F, Dasar-Dasar Hukum Pidana Indonesia, Citra Aditya Bakti, Bandung: 2011.

Marpaung, Leden, Tindak Pidana Terhadap Kehormatan, RajaGrafindo Persada, Jakarta: 2006.

Moeljatno, Asas-asas Hukum Pidana, Rineka Cipta, Jakarta: 2008.

Pusat Bahasa Departemen Pendidikan Nasional, Kamus Besar Bahasa Indonesia, Balai Pustaka, Jakarta: 2002.

Setiyono, Kejahatan Korporasi: Analisis Viktimologi dan Pertanggungjawaban Korporasi dalam Hukum Pidana Indonesia, Bayu Media, Malang: 2003.

Sjahdeni, Sutan Remy, Pertanggungjawaban Pidana Korporasi, Grafi Pers, Jakarta: 2007.

Soesilo, R., Kitab Undang-Undang Hukum Pidana (KUHP) Serta Komentar-Komentarnya Lengkap Pasal Demi Pasal, Politea Bogor, Bandung: 1998.

Sukardi, Wina Armada, Asas Praduga Tidak Bersalah Dalam Praktek Pers, Dewan Pers, Jakarta: 2010.

Susanto, Edy, Muhammad Taufik Makarao, Hamid Syamsudin, Hukum Pers di Indonesia, Rineka Cipta, Jakarta: 2012.

\section{Sumber Lain}

Tim Dosen Kapita Selekta Hukum Pidana, Handout Kapita Selekta Hukum Pidana, Laboratorium Hukum Pidana Universitas Surabaya, Surabaya, 2018.

Tim Dosen Kejahatan Korporasi, Handout Kejahatan Korporasi, Laboratorium Hukum Pidana Universitas Surabaya, Surabaya, 2018. 
http://m.tribunnews.com/nasional/2014/07/18/diberitakan-tertangkap-kpk-arya-sinulinggapolisikan-tempo-online. (Diakses pada 5/12/2018)

http://rakyatsulsel.com/arya-sinulingga-laporkan-tempo-kemabes-polri-html. (Diakses pada $5 / 12 / 2018)$ 